\title{
Alternatively Spliced Sodium Channel Transcripts in Brain and Muscle
}

\author{
K. L. Schaller, D. M. Krzemien, N. M. McKenna, and J. H. Caldwell \\ Departments of Cellular and Structural Biology and of Physiology, and the Neuroscience Program, University of Colorado \\ Health Sciences Center, Denver, Colorado 80262
}

\begin{abstract}
Sodium (Na) channel cDNAs were synthesized from RNA isolated from rat brain, cardiac muscle, and skeletal muscle. Partial cDNAs coding for the largest cytoplasmic loop of the $\mathrm{Na}$ channel were amplified with PCR. Sequence analysis of these CDNAs revealed that $\mathrm{Na}$ channel CDNAs originally described as brain genes were also expressed in both cardiac and skeletal muscle. Some of these cDNAs were isoforms that differed by insertions or deletions and can be explained by alternative choices of a $5^{\prime}$ splice site. Southern blot analysis of genomic DNA confirmed the presence of introns in this region of the gene. Transcripts of multiple isoforms were detected with RNase protection in brain, heart, and skeletal muscle.

Several conclusions can be drawn from the data. (1) Some rat sodium channel genes are transcribed in all excitable tissues studied here: brain, cardiac muscle, and skeletal muscle. (2) Each of these three tissues expresses multiple sodium channel genes. (3) Alternative splicing of sodium channel transcripts occurs in these tissues. (4) Expression of multiple genes and alternative splicing of the transcripts is responsible for at least seven different sodium channel mRNAs in skeletal muscle.
\end{abstract}

A remarkable feature of $\mathrm{Na}$ channels is their electrophysiological similarity across phyla; $\mathrm{Na}$ currents in squid and mammals look almost identical. The similarity of channel kinetics between phyla implies that the basic channel form has been conserved for millions of years. Despite this preservation of elementary channel function, $\mathrm{Na}$ channels in different organisms can be distinguished, and different subtypes have been described within a single organism. Pharmacological studies with toxins reveal differences between neuronal and muscle $\mathrm{Na}$ channels and between innervated and denervated muscle (Redfern and Thesleff, 1971; Olivera et al., 1990). Single-channel recordings show a difference in conductance between TTX-sensitive and TTXresistant $\mathrm{Na}$ channels (Weiss and Horn, 1986). Studies with antibodies against the sodium channel indicate differences betwecn t-tubule system and surface membrane $\mathrm{Na}$ channels as

\footnotetext{
Received Aug. 9, 1991; revised Nov. 4, 1991; accepted Nov. 6, 1991.

We thank Drs. Gail Mandel and Peter Sarnow for criticisms and suggestions for the manuscript. We thank Kay Hahne for preparation of the manuscript. This work was supported by NIH Training Grant NS07083 and NRSA Grant NS08870 (K.L.S.) and NIH grant NS26505 (J.H.C.).

Correspondence should be addressed to Dr. John $\mathbf{H}$. Caldwell, Department of Cellular and Structural Biology, U.C.H.S.C. Box B-111, 4200 East 9th Avenue, Denver, CO 80262.

Copyright (c) 1992 Society for Neuroscience $0270-6474 / 92 / 121370-12 \$ 05.00 / 0$
}

well as between $\mathrm{Na}$ channels in the tubule membrane of fasttwitch versus slow-twitch muscle (Haimovich et al., 1987). These subtypes could be the consequence of multiple genes, posttranscriptional processing (e.g., alternative splicing of the RNA), posttranslational modifications, different environments (e.g., lipid domains), association with other subunits ( $\beta$-subunits found in brain and muscle), or a combination of these mechanisms.

The isolation of four different $\mathrm{Na}$ channel cDNAs from rat brain cDNA libraries (Noda et al., 1986a; Auld et al., 1988; Kayano et al., 1988) led to the expectation that some of the observed $\mathrm{Na}$ channel phenotypes would be based on differences in the $\mathrm{Na}$ channel genes expressed. Evidence supporting the idea that each gene product serves specialized roles comes from kinetic, immunocytochemical, and RNA hybridization studies. Sodium channels II, IIA, and III show slightly different kinetics when expressed in Xenopus oocytes (Noda et al., 1986b; Auld et al., 1988, 1990; Suzuki et al., 1988; Joho et al., 1990). Musclespecific (Haimovich et al., 1987) and brain-specific (Wollner and Catterall, 1985, 1986; Gordon et al., 1987; Westenbroek et al., 1989) antibodies have been used to show tissue-specific expression and differential subcellular localization. RNA hybridization analysis has shown that there are devclopmental changes and tissue differences for cDNAs isolated from brain (Suzuki et al., 1988; Beckh et al., 1989; Beckh, 1990) and muscle (Kallen et al., 1990; Trimmer et al., 1990).

Multiple $\mathrm{Na}$ channel cDNAs have been isolated and sequenced from rat tissues: four from brain $[\mathrm{NaCh} \mathrm{I}$ and $\mathrm{NaCh}$ II (Noda et al., 1986a), NaCh IIA (Auld et al., 1988), NaCh III (Kayano et al., 1988)], two from skeletal muscle [ $\mu 1$ (Trimmer et al., 1989) and SkM2 (Kallen et al., 1990)], and two from cardiac muscle [RH 1 (Rogart et al., 1989) and CSC (Sills et al., 1989)]. NaCh II and IIA have only six amino acid differences, and SkM2 and RH1 are virtually identical. Comparisons of primary amino acid sequences show that the regions thought to be transmembrane are highly similar, while the cytoplasmic and extracellular regions tend to be more variable. We have used this pattern of conserved regions with intervening variable regions to isolate novel $\mathrm{Na}$ channel transcripts.

DNA amplification by PCR is ideal for the isolation of additional genes once a gene or protein sequence is known. We have used this method to isolate different cDNAs from brain, as well as from cardiac and skeletal muscle. Some cDNAs are transcribed from separate genes, while others (which we call isoforms) are due to alternative splicing. These transcripts all vary in a single region and can be explained by simple insertions or deletions. This suggests that alternative splicing is a common feature of $\mathrm{Na}$ channel mRNA processing. In addition, both skeletal and cardiac muscle contained mRNAs that were originally 
described from rat brain ( $\mathrm{NaCh}$ I and $\mathrm{NaCh}$ III). Skeletal muscle, for example, can contain at least seven different mRNAs for the $\mathrm{Na}$ channel. If all of these transcripts are translated into functional proteins, there is a surprising number of muscle isoforms. The purpose of this diversity in a cytoplasmic domain is unknown; two possibilities are modulation of channel activity and localization of $\mathrm{Na}$ channels in different cells or different regions of a cell.

\section{Materials and Methods}

Nomenclature. We have employed the abbreviations used by Beckh et al. (1989) for the three cDNAs originally isolated from brain (Noda et al., 1986; Kayano et al., 1988). Abbreviations for the other published cDNAs conform to the original articles. The alternative splicing variants have been denoted with a lowercase letter following the abbreviation.

PCR amplification primers. We chose two regions [29 and 30 nucleotides in length] that had two mismatches between the three rat brain $\mathrm{NaCh}$ I, II, and III genes and four mismatches with the eel gene. The oligonucleotide primers (Table 1) were synthesized with two restriction enzyme sequences on the $5^{\prime}$ ends to allow the amplified DNA to be subcloned into phage vectors. For amplification of the $\mathrm{Na}$ channel, the $5^{\prime}$ primer had Sall and HindIII restriction sitcs at the 5' end and the $3^{\prime}$ primer had SphI and EcoRI restriction sites. The amplified region between the primers was about 1 kilobase (ranging from 1100 nucleotides for $\mathrm{NaCh}$ I to 941 nucleotides for $\mathrm{NaCh}$ III) and is the largest cytoplasmic domain.

$R N A$ extraction, $c D N A$ synthesis, and $P C R$ amplification. Tissues were removed and either stored at $-80^{\circ} \mathrm{C}$ or immediately homogenized. Total cellular RNA was isolated with a single-step guanidinium thiocyanate acid-phenol chloroform extraction (Chomczynski and Sacchi, 1987). Oligo(dT)-primed synthesis of cDNA was done in $50 \mu$ l containing 1 $\mu \mathrm{g}$ of total RNA, $50 \mathrm{~mm}$ Tris (pH 8.3), $75 \mathrm{~mm} \mathrm{KCl,} 3 \mathrm{~mm} \mathrm{MgCl}_{2}, 5$ mM dithiothreitol (DTT), $100 \mathrm{ng}$ of oligo(dT), $500 \mu \mathrm{M}$ dNTPs (deoxynucleotide triphosphates), and $200 \mathrm{U}$ of Moloney murine leukemia virus reverse transcriptase from Bethesda Research Laboratories. The synthesis was carried out at $25^{\circ} \mathrm{C}$ for $5 \mathrm{~min}, 30^{\circ} \mathrm{C}$ for $5 \mathrm{~min}$, and $37^{\circ} \mathrm{C}$ for $90 \mathrm{~min}$. The concentrations and components were designed so that the PCR amplification could be carried out simply by adding primers (1 $\mu_{\mathrm{M}}$ final concentration) and Taq polymerase ( $\left.1 \mathrm{U}\right)$ and diluting with $\mathrm{H}_{2} \mathrm{O}$ to $100 \mu \mathrm{l}$.

An amplification cycle consisted of denaturing the DNA at $94^{\circ} \mathrm{C}$ for $2 \mathrm{~min}$, annealing the primers at $48^{\circ} \mathrm{C}$ for $2 \mathrm{~min}$, and elongation of the primers at $72^{\circ} \mathrm{C}$ for $3-4 \mathrm{~min}$. Five cycles were done with these conditions. Another 30 cycles were done with the annealing temperature raised to $58^{\circ} \mathrm{C}$ because after the first few cycles the 14 nucleotides that are sites for restriction enzymes will also hybridize and thus increase the $T_{m}$. Amplifications were performed on a Tempcycler (Coy Laboratory Products, Inc.).

Gel and Southern blot analysis of PCR products. To analyze the reaction products, typically $10 \mu \mathrm{l}$ was run on a $5 \%$ polyacrylamide gel in $1 \times$ TBE $(0.089 \mathrm{M}$ Tris, $0.089 \mathrm{M}$ borate, $0.002 \mathrm{M}$ EDTA) and visualized by ethidium bromide fluorescence. The amplified DNA was electrophoretically transferred to a charged nylon membrane (ZetaProbe, BioRad) with a Bio-Rad semidry electrophoresis unit in $0.5 \times$ TBE at 400 $\mathrm{mA}$ for $1 \mathrm{hr}$. The membrane was prehybridized in $6 \times$ saline-sodium citrate (SSC; $1 \times$ SSC contains $0.15 \mathrm{M} \mathrm{NaCl}, 0.15 \mathrm{M}$ Na citrate, $\mathrm{pH} \mathrm{7.0)}$ ), $5 \times$ Denhardt's $(0.1 \%$ bovine serum albumin, $0.1 \%$ Ficoll, and $0.1 \%$ polyvinylpyrrolidone), $1 \%$ SDS, $100 \mu \mathrm{g} / \mathrm{ml}$ denatured salmon sperm DNA, and $50 \mu \mathrm{g} / \mathrm{ml}$ yeast $t$ RNA at $45^{\circ} \mathrm{C}$ for $2-4 \mathrm{hr}$ and hybridized overnight in the same buffer with the addition of $5 \times 10^{5}$ to $1 \times 10^{6}$ $\mathrm{cpm} / \mathrm{ml}$ of oligonucleotides (internal to the amplification primers) that were end labeled with $\gamma_{-}{ }^{32} \mathrm{P}$-ATP. The membranes were washed twice in $2 \times \mathrm{SSC}, 1 \% \mathrm{SDS}$ at $25^{\circ} \mathrm{C}$ and twice in $2 \times \mathrm{SSC}, 1 \% \mathrm{SDS}$ at $45^{\circ} \mathrm{C}$ and exposed to $\mathrm{x}$-ray film for $2-4 \mathrm{hr}$. The sequences for $\mathrm{Na}$ chanmel internal oligonucleotide probes 1 and 2 and for the $\mathrm{Na}^{+} / \mathrm{K}^{+}$-ATPase internal oligonucleotide probe are given in Table 1 .

DNA sequence analysis. After successful amplification of Na channels, as indicated by Southern analysis, usually one-half of the amplification reaction either was digested directly with SphI and SalI restriction enzymes and subcloned into the RF forms of the filamentous phage M13 mpl 8 and mpl9 (also restricted with the enzymes SphI and SalI), or was size selected on a $1 \%$ agarose gel, purified by Gene Clean (Bio 101) according to the manufacturer's instructions, and then digested with
SphI and SalI. The recombinant phage DNA was used to transform Escherichia coli strain JM109, noncolored M13 plaques were selected, and template DNA was prepared as described by Messing (1983). The DNAs were sequenced by the dideoxy method with a series of internal oligonucleotide primers using Sequenase (United States Biochemical) according to the manufacturer's instructions. The homology comparisons were done using PC GENE software (Intelligenetics).

Genomic DNA Southern analysis. Rat genomic DNA was digested with several restriction enzymes; the DNA ( $10 \mu \mathrm{g} /$ lane $)$ was fractionated on a $1 \%$ agarose gel in $1 \times$ TBE buffer and was transferred to a nylon membrane (Micron Separations, Inc.) as described by Southern (1975). The membrane was prehybridized with $50 \%$ formamide, $5 \times$ Denhardt's solution, $6 \times \mathrm{SSC}, 0.1 \% \mathrm{SDS}$, and $100 \mu \mathrm{g} / \mathrm{ml}$ of denaturcd salmon sperm DNA at $45^{\circ} \mathrm{C}$ for $4 \mathrm{hr}$. The membrane was hybridized in this same buffer with the addition of $1-2 \times 10^{6} \mathrm{cpm} / \mathrm{ml}$ of $\mathrm{NaCh}$ IIIl ${ }^{32} \mathrm{P}$-labeled probe at $45^{\circ} \mathrm{C}$ for $36-40 \mathrm{hr}$. The membrane was washed twice in $2 \times$ SSC, $0.1 \%$ SDS at $25^{\circ} \mathrm{C}$; twice in $2 \times \mathrm{SSC}, 0.1 \%$ SDS at $65^{\circ} \mathrm{C}$; and twice in $0.2 \times \mathrm{SSC}, 0.1 \% \mathrm{SDS}$ at $65^{\circ} \mathrm{C}$ and exposed to $\mathrm{x}$-ray film. The membrane was stripped in $10 \mathrm{~mm}$ Tris, $1 \mathrm{~mm}$ EDTA at $75^{\circ} \mathrm{C}$ and then rehybridized with a $\mathrm{NaCh}$ III probe as described above. The ${ }^{32} \mathrm{P}$-labeled probes were generated by PCR using M13 template DNAs and internal oligonucleotide primers 2 and 3 (Table 1). The concentration of the dNTPs used are as follows: dGPT, dTTP, and dATP at $250 \mu \mathrm{M}$; dCTP at $25 \mu \mathrm{M}$. A $150 \mu \mathrm{Ci}$ quantity of $\alpha{ }^{32} \mathrm{P}$-dCTP (Amersham) was added per $25 \mu \mathrm{l}$ reaction. The PCR conditions remained the same except the annealing temperature was lowered to $40^{\circ} \mathrm{C}$ and the extension times dccrcased to $2 \mathrm{~min}$.

RNase protection assay. The Na channel isoforms were PCR amplified from M13 phage DNA with Na channel internal oligonucleotide 3 and 2 as $5^{\prime}$ and $3^{\prime}$ primers (Table 1 ) as described above, except that the annealing temperature was $40^{\circ} \mathrm{C}$. The products were blunt-end ligated into a filled-in BamHI site of pGem 4 vector (Promega). cRNA was prepared by in vitro transcription using either T7 or SP6 polymerase on the linearized template in the presence of $\alpha{ }^{32} \mathrm{P}-\mathrm{CTP}$ (Amersham) as described by Promega and precipitated twice with ethanol and ammonium acetate. Counts $\left(5 \times 10^{5}\right)$ of the cRNA probe were annealed to $50 \mu \mathrm{g}$ of total RNA in $40 \mathrm{~mm} 1,4$-piperazinediethanesulfonic acid, pH $6.4,0.4 \mathrm{M} \mathrm{NaCl}, 1 \mathrm{~mm}$ EDTA, and $80 \%$ formamide overnight at $45^{\circ} \mathrm{C}$. The unhybridized RNA and probe were digested at $30^{\circ} \mathrm{C}$ with 40 $\mu \mathrm{g} / \mathrm{ml}$ RNase A (Boehringer-Mannheim) and $2 \mu \mathrm{g} / \mathrm{ml}$ RNase T1 (Bethesda Research Laboratories) for $30 \mathrm{~min}$. The protected probes were analyzed on a $6 \%$ polyacrylamide, $8 \mathrm{M}$ urea gel and exposed to $\mathrm{x}$-ray film. The relative abundance of each isoform was estimated by densitometer measurements from autoradiographs. In one case, the densitometer results were confirmed by direct measurements of radioactive decay using an Ambis Gel Scanner.

Controls for nonspecific hybridization consisted of (1) the sense strand for each probe and (2) antisense probe hybridized to liver RNA or to $t$ RNA. No signal was present in any of the controls.

\section{Results}

We isolated transcripts for the Na channel using the PCR method of DNA amplification (Saiki et al., 1988). For the primers, we chose two highly conserved regions that span an extremely variable region of the gene (Fig. 1). The $5^{\prime}$ conserved region was near the end of the first large transmembrane domain (IS6), and the $3^{\prime}$ conserved region was at the beginning of the second large transmembranc domain (IIS1). The only vertebrate Na channel sequences published when these studies were begun were the eel (Noda et al., 1984) and three rat brain cDNAs (Noda et al., 1986a; Kayano et al., 1988); a partial cDNA sequence from Drosophila had been reported (Salkoff et al., 1987).

cDNAs were synthesized from total RNA isolated from rat tissue (brain, kidney, cardiac muscle, and skeletal muscle). In addition to amplification of the $\mathrm{Na}$ channel cDNAs, as a positive control a portion of the $\mathrm{Na}^{+} / \mathrm{K}^{+}$-ATPase was amplified from the same RNA preparation. The amplified ATPase DNA was visualized by ethidium bromide fluorescence of polyacrylamide gels and was present in all tissues (Fig. 2A). Several DNAs of the size predicted for $\mathrm{Na}$ channel were observed in brain, heart, 
A.

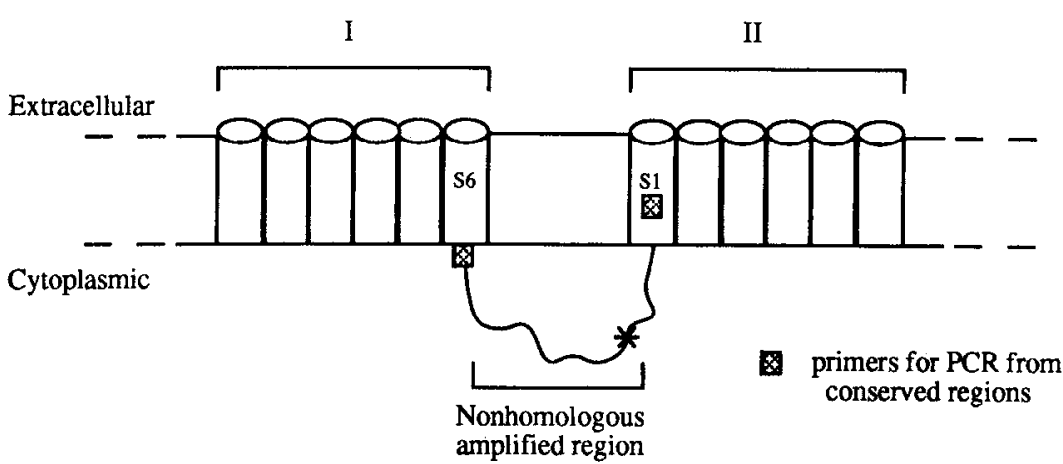

B.

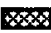

$50001100 \mathrm{nt}$

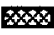

1077 II

Figure 1. Amplified region of the Na channel. $A$, The 5 half of the proposed secondary structure of the Na channel. The amplified region is between the crosshatched boxes. The asterisk in the amplified region indicates where alternative splicing was detected. $B$, The lengths of the rat brain and eel electric organ cDNAs between the primers. Open bars indicate homologous regions that are missing in some cDNAs and create the variability in length. The boxes labeled 1 and 2 at the bottom indicate the positions of the oligonucleotides used as probes for Southern analysis.

and skeletal muscle. There was no Na channel amplification from adult kidney RNA. The Na channel in kidney is likely to be unrelated to the voltage-gated $\mathrm{Na}$ channel since the kidney $\mathrm{Na}$ channels are amiloride sensitive with weak voltage dependence. Thus, the absence of amplified DNA from kidney was expected. Moreover, Beckh (1990) detected voltage-gated $\mathrm{Na}$ channel mRNA with Northern blots of RNA from early postnatal kidney but not adult kidney.

The amplified DNAs in Figure 2 agreed with the predicted sizes. To confirm that these were $\mathrm{Na}$ channel and ATPase cDNAs, oligonucleotide sequences internal to the PCR primers (see Fig. 1, Table 1) were used as probes for Southern blot analysis. The ATPase probe hybridized to the appropriate band in all tissues (not shown). Two internal $\mathrm{Na}$ channel probes were used: one probe (" 1 " at bottom of Fig. 1) is present in $\mathrm{NaCh} \mathrm{I}$ and $\mathrm{NaCh}$ II but not in $\mathrm{NaCh}$ III (or eel), while the other probe (" 2 " at bottom of Fig. 1) is present in all three rat brain genes and the eel gene. Internal probe 1 produced an intense hybridization signal with brain DNA at the appropriate size, a single heavy band with cardiac DNA and a faint band with skeletal muscle DNA (Fig. $2 B$ ). Internal probe 2, which was more generic, hybridized with additional bands (Fig. $2 C$ ) in each of these three tissues. The autoradiograms confirmed that the ethidium bromide-stained DNAs were $\mathrm{Na}$ channel DNA. Once the Na channel amplification was confirmed by Southern analysis, the amplified DNAs were subcloned and sequenced from brain, cardiac muscle, and skeletal muscle.

\section{Brain CDNAs}

$\mathrm{Na}$ channels were amplified from brain to demonstrate that the strategy would work on a tissue where known $\mathrm{Na}$ channel genes were expressed. Hence, only four clones were sequenced from amplified brain cDNA. Two clones were $\mathrm{NaCh}$ I with a 33 nucleotide deletion, which we designate $\mathrm{NaCh}$ Ia. Noda et al. (1986) described this isoform in brain and did an S1 nuclease assay to exclude the possibility that $\mathrm{NaCh}$ Ia was a cloning artifact. RNase protection assays that compare the abundance of $\mathrm{NaCh} \mathrm{I}$ and Ia transcripts show that $\mathrm{NaCh} \mathrm{Ia}$ is the predominant transcript (see below). The other two clones were rat brain IIA. This classification as IIA is based on two nucleotide differences between $\mathrm{NaCh}$ II and IIA in the region we amplified. It is not surprising that we did not find $\mathrm{NaCh}$ III since it is present at very low levels in adult brain (Beckh et al., 1989). 
A.

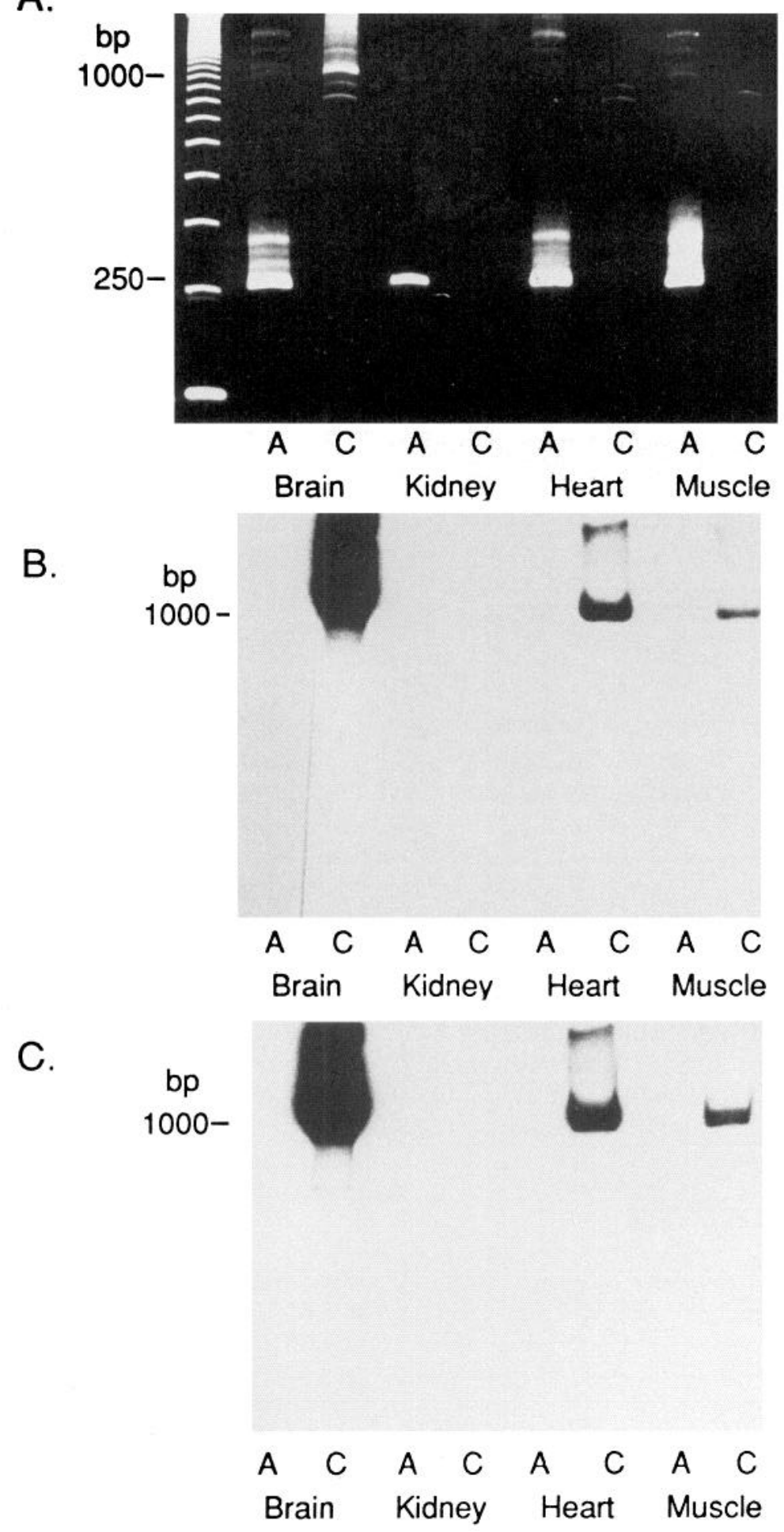

$-\mathrm{Na}$ Channel

$-\mathrm{N} / \mathrm{K}$ ATPase
Figure 2. Analysis of PCR reaction products. $A$, Ethidium bromide-stained polyacrylamide gel. Amplification with $\mathrm{Na}^{+} / \mathrm{K}^{+}$-ATPase primers (lanes labeled $A$ ) from rat brain, kidney, cardiac muscle, and skeletal muscle produced DNA at the expected size ( 246 nucleotides). $\mathrm{Na}$ channel primers amplified DNA about 1000 nucleotides in length from the brain, cardiac muscle, and skeletal muscle but not kidney (lanes labeled $C$ ). The marker lane on the left is a 123 base pair ladder (Bethesda Research Laboratories). $B$ and $C$, Southern analysis of DNA from the gel in $A$ with probe $1(B)$ and probe $2(C)$. Additional bands appear with the more generic probe $(C)$, and a doublet is visible for skeletal muscle $(C)$.

\section{Cardiac muscle cDNAs}

Several clones were isolated and sequenced from amplification products of rat heart cDNA. Three different transcript variants were isolated: $\mathrm{NaCh} \mathrm{I,} \mathrm{NaCh}$ Ia, and $\mathrm{NaCh}$ III. These variants are illustrated in Figure 3.

\section{Skeletal muscle cDNAs}

Numerous Na channel cDNAs were sequenced; these could be divided into six types. Five of these are illustrated in Figure 3. Both $\mathrm{NaCh}$ I and $\mathrm{NaCh}$ Ia were found; these were identical to $\mathrm{NaCh} \mathrm{I}$ and $\mathrm{NaCh}$ Ia from brain and cardiac muscle, described 
IS6 IIS1

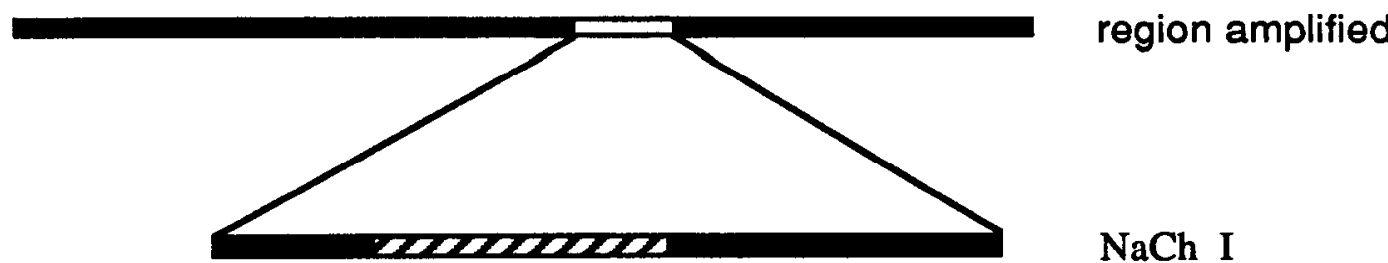

$\mathrm{NaCh} \mathrm{I}$

2000000

$\mathrm{NaCh} \mathrm{Ia}$

$\mathrm{NaCh}$ III

\$OS

$\mathrm{NaCh}$ IIIa

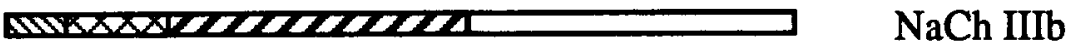

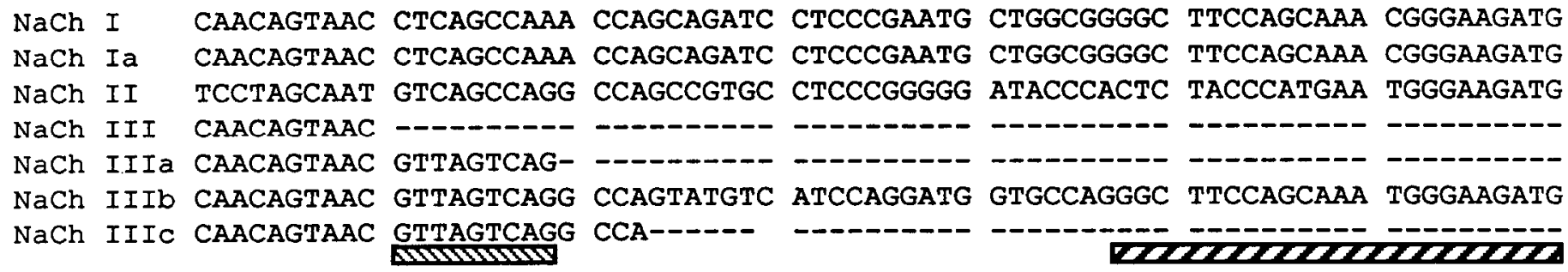

NaCh I CACAGCACAg TGGATtgCAA TGGTGTGGTT TCCTTGGTgG GCGgACCCTC GGTTCCGACA TCGCCAGTTG $\mathrm{NaCh}$ Ia CACAGCACAG TGGATTGCAA TGGTGTGGTT TCCTTGGTGg GCGGACCCTC GGTTCCGACA TCGCCAGTTG $\mathrm{NaCh}$ II CACAGTGCAG TGGACTGCAA CGGTGTGGTG TCCCTGGTTG GAGGCCCCTC TGCGCTCACA TCGCCTGTGG

$\mathrm{NaCh}$ III

$\mathrm{NaCh}$ IIIa

$\mathrm{NaCh}$ IIIb

$\mathrm{NaCh}$ IIIC

$$
\text { C }
$$

CACAGCACTG TGGATTGCAA TGGTGTGGTT TCCTTG----

-

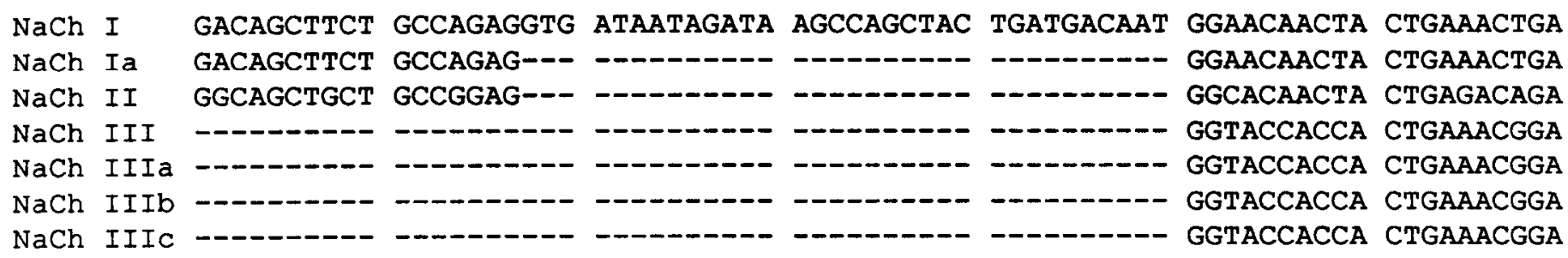

Figure 3. Schematic indicating the amplified cDNAs of cardiac and skeletal muscle with the nucleotide sequences in the variable region given below. All variability occurs in one region, indicated by the asterisk in Figure $1 A$. NaCh I and NaCh Ia differ only by the deletion of 33 nucleotides in $\mathrm{NaCh}$ Ia (open bar). The open bar in NaCh III indicates a region present in $\mathrm{NaCh}$ I that is missing in $\mathrm{NaCh}$ III. NaCh IIIa has nine nucleotides inserted (thin diagonal lines in both upper and lower half of figure). $\mathrm{NaCh}$ IIIb has 96 nucleotides inserted; the first 9 are identical to NaCh IIIa, and the last 60 are almost identical to the homologous region of $\mathrm{NaCh}$ I (thick diagonal lines). The remaining 27 nucleotides (crosshatched) are not conserved. The nucleotide sequence of the entire first cytoplasmic loop of NaCh III agreed with Joho et al. (1990) and differed from Kayano et al. (1988) at two positions (nucleotides 1929 and 1966 of Kayano et al.; nucleotides 2077 and 2114 of Joho et al.); the second of these causes an amino acid change from serine to alanine. 
Table 1. Oligonucleotides used

\begin{tabular}{llll} 
& \multicolumn{1}{l}{ Position } & Sequence \\
\hline $\mathrm{Na}^{+} / \mathrm{K}^{+}$-ATPase & $5^{\prime}$ & $1191-1214$ & CCGAATTCGTCGACCGAGGCTGTCATCTTCCTCATTGG \\
& $3^{\prime}$ & $1412-1436$ & CGGGATCCAAGCTTGCTTCATGGATTTGATTGTCAAACC \\
$\mathrm{NaCh}$ & Int & $1305-1324$ & CTTCCAGGTTCTTCACCAGG \\
& $5^{\prime}$ & $1306-1335$ & CCAAGCTTGCATGCGAGGCTGAACAGAAGGAGGCAGAGTTTCAG \\
& $3^{\prime}$ & $2350-2378$ & CCGAATTCGTCGACGTCATGGGGTAGTGCTCCATGGCCATGAA \\
& Int 1 & $1912-1928$ & CTGTGCATCTTCCC(G/A)TT \\
& Int 2 & $2181-2197$ & TTCTGTCT(G/A)GATTCTTC \\
& Int 3 & $1755-1772$ & GACTTTGCAGACGATGAG
\end{tabular}

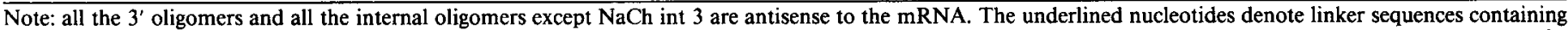

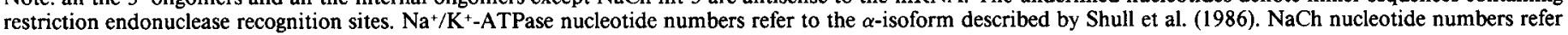
to rat brain sodium channel I (Noda et al., 1986a).

above. The other three cDNA variants illustrated in Figure 3 were isoforms of $\mathrm{NaCh}$ III. One isoform was identical to $\mathrm{NaCh}$ III, a second was $\mathrm{NaCh}$ III with a 9 nucleotide insert that we designate $\mathrm{NaCh}$ IIIa, and the third was $\mathrm{NaCh}$ III with a 96 nucleotide insert that we designate $\mathrm{NaCh}$ IIIb. The sixth type of cDNA was $\mathrm{NaCh}$ III with a 13 nucleotide insert. The 9 and 13 nucleotide inserts were identical to the beginning of the 96 nucleotide insert of $\mathrm{NaCh}$ IIIb. The 13 nucleotide insert would result in a truncated protein four amino acids downstream from the insert. The $\mathrm{NaCh}$ IIIb sequence has also recently been reported by Joho et al. (1990) who isolated it from a rat brain cDNA library.

\section{Genomic DNA}

All of the isoforms described above are deletions or insertions in a single region of the gene. This suggests that the isoforms arise by alternative splicing of the RNA. To test for the existence of introns in this region, genomic DNA was digested with several restriction enzymes, and Southern analysis was performed with two NaCh III probes: one included the 96 nucleotide insert and the second was lacking the insert (see Fig. 4 caption).

A diagram of the entire cDNA for $\mathrm{NaCh}$ III and the sites for the restriction enzymes is illustrated in Figure $4 A$; the bottom line of Figure $4 A$ indicates the region amplified in these experiments. An autoradiograph of the resulting DNA hybridization is shown in Figure $4 B$. A single band was observed in the EcoRI lane with multiple bands in all other lanes. The expected size of the labeled DNA if no introns existed, compared to the size of the bands in Figure $4 B$, is given in Table 2. For several enzymes, the bands are much larger than predicted for an intronless gene. Although the Southern was washed at high stringency, some of the bands could be due to hybridization to ho- mologous $\mathrm{Na}$ channel genes. Onc argument against nonspecific hybridization is that the identical pattern of bands was obtained regardless of whether or not the probe included the 96 nucleotide insert. Moreover, nonspecific binding could not account for the fact that some bands are much larger than those predicted when assuming no introns. The size of these bands allows an estimate of the minimum amount of intervening sequence in the regions between the restriction sites: 21 kilobases (Kpn I digest), 4 kilobases (Pst I digest), and 6 kilobases (Hind III digest).

\section{RNase protection}

PCR amplification is capable of producing micrograms of DNA from a single molecule. This exquisite sensitivity allows one to detect cDNAs that are unmeasurable by any other means. The $\mathrm{Na}$ channel cDNAs that we have cloned from muscle were originally isolated from rat brain. Are these present in any significant amount in muscle? There have been conflicting reports concerning the presence of some rat brain $\mathrm{Na}$ channel mRNAs in muscle (Cooperman et al., 1987; Suzuki et al., 1988; Rogart et al., 1989; Beckh, 1990). We tested for the presence and relative abundance of the $\mathrm{Na}$ channel isoforms in brain, cardiac muscle, and skeletal muscle with RNase protection. The sizes expected to be protected by an antisense riboprobe are indicated in Figure $5 A$. A comparison of the full length protected $\mathrm{NaCh} \mathrm{I}$ and $\mathrm{NaCh}$ III probes is given in Figure $5 B$.

The abundance of each probe was about 10 -fold greater in brain than in muscle and was roughly equivalent between the three lanes of muscle (see Fig. 5 caption for quantitation). $\mathrm{NaCh}$ Ia was much more abundant than $\mathrm{NaCh} \mathrm{I}$ in brain (9.5-fold, see Fig. 5C) and muscle (2.9-fold, data not shown). When $\mathrm{NaCh}$ I probe hybridized to $\mathrm{NaCh}$ Ia mRNA, an internal region of 33 nucleotides was unhybridized and cut by RNase, leaving two

Table 2. Restriction enzyme fragment sizes of rat genomic DNA

\begin{tabular}{|c|c|c|c|c|c|c|c|c|}
\hline & \multicolumn{8}{|l|}{ Enzyme } \\
\hline & Kpn I & EcoRI & Bam HI & Xba I & Pst I & Hind III & Hae III & Rsa I \\
\hline Predicted sizes if no introns & $2,>4$ & $>6$ & $>2.9$ & $>2.7$ & 2.6 & 1.5 & $0.6,0.4$ & $1,>4.3$ \\
\hline Observed sizes & $>23$ & 8 & 20,23 & $3,5,20$ & $6.6,20$ & $7.5,15$ & $\begin{array}{l}0.6,1.0 \\
1.5,2.8\end{array}$ & $\begin{array}{l}1.0,0.8 \\
2.3\end{array}$ \\
\hline Predicted number & 2 & 1 & 1 & 2 & 1 & 1 & 2 & 2 \\
\hline Observed number & 3 & 1 & 2 & 3 & 2 & 2 & 4 & 3 \\
\hline
\end{tabular}

Sizes in kilobases. Two faint bands for Hind digestion ( $\sim 3$ kilobases and $\sim 5$ kilobases) have not been counted. 
A.
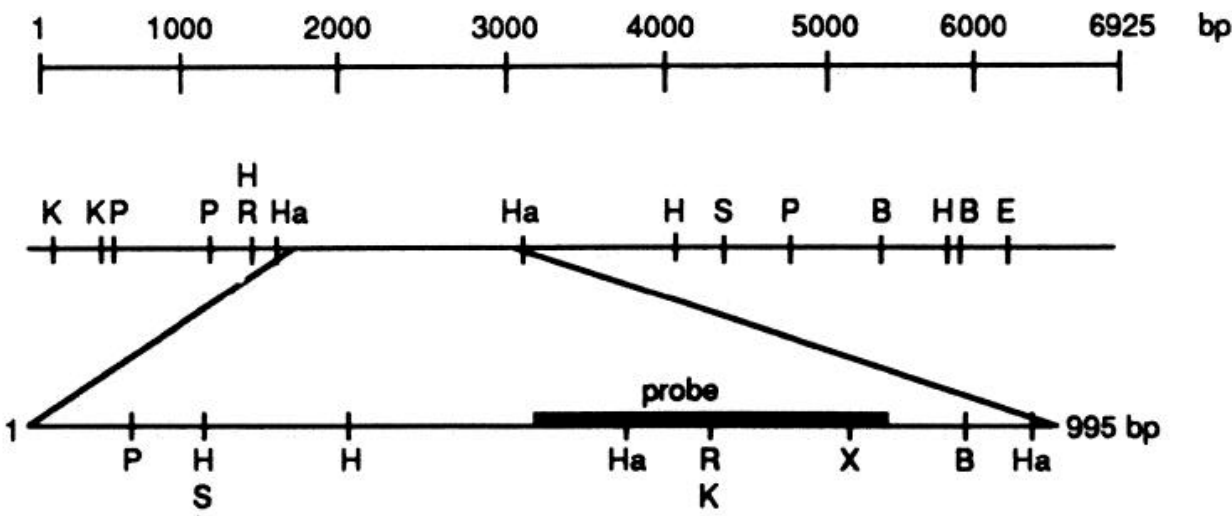

B.

Figure 4. Southern analysis of restriction enzyme digest of rat genomic DNA. $A$, Upper diagram indicates the cDNA length of $\mathrm{NaCh}$ III (upper row) and relevant restriction sites (middle and bottom row): $K, \mathrm{KpnI} ; E, \mathrm{EcoRI} ; B$, BamH1; $X$, XbaI; $P$, PstI; $H$, HindIII; $H a$, HaeIII; R, RsaI. Bottom row indicates the amplified region and the position of the radiolabeled probe. $B$, Autoradiogram of genomic DNA cut with restriction enzymes (top of each lane). The probe was either $\mathrm{NaCh}$ III with a length of 254 (nucleotides 1774 to 2027) or $\mathrm{NaCh}$ IIIb with a length of 350 (identical to the NaCh III probe but containing the 96 nucleotide insert). Identical bands were obtained with each probe. Marker was $\lambda$-DNA digested with HindIII.

\section{Kpn Eco Bam Xba Pst Hind Hae Rsa}

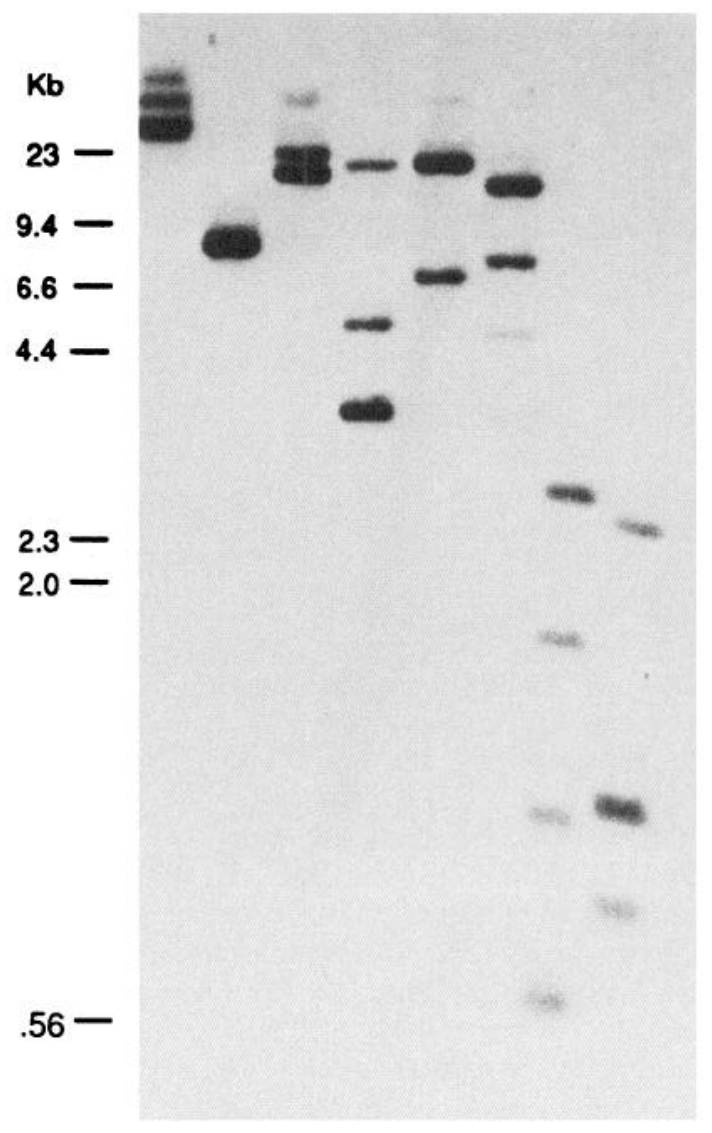

smaller bands (156 and 246 nucleotides). The total signal from these bands (Fig. $5 C$, lane 1) was equal to that from the fully protected band (Fig. $5 C$, lane 2).

The isoforms of $\mathrm{NaCh}$ III were readily detectable in brain, normal skeletal muscle, and denervated skeletal muscle (Fig. $5 D$ ) as well as in cardiac muscle (not shown). The ratio $\mathrm{NaCh}$ III:NaCh IIIa: $\mathrm{NaCh}$ IIIb was about 1:0.4:0.1 in all three tissues and in denervated muscle. The isoform of $\mathrm{NaCh}$ III with a 13 nucleotide insert was about $5 \%$ as abundant as $\mathrm{NaCh}$ III.

The rat brain $\mathrm{NaCh} \mathrm{I}$ and III isoforms are not the major $\mathrm{Na}$ channel RNAs in skeletal muscle. A rat $\mu 1$ probe gave a signal 20 times greater than either $\mathrm{NaCh} \mathrm{I}$ or $\mathrm{NaCh}$ III for skeletal muscle (data not shown). Thus, although the rat brain cDNAs ( $\mathrm{NaCh}$ I and $\mathrm{NaCh}$ III) are easily detectable in muscle and are about one-tenth as abundant as in brain, rat $\mu 1$ is the dominant $\mathrm{Na}$ channel mRNA in muscle.

In addition to providing an estimate of the abundance of the various mRNAs, we conclude from RNase protection analysis that there is no obvious tissue specificity in adult rats for the splicing. Moreover, there were no dramatic changes in the levels 
Fully Protected Probe

$\mathrm{NaCh}$ I

$\mathrm{NaCh}$ la

$\mathrm{NaCh}$ III

$\mathrm{NaCh}$ Illa

$\mathrm{NaCh}$ IIlb
435

402

254

263

350

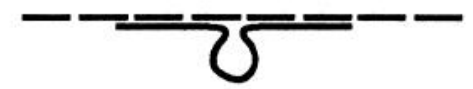

Protected Fragments

156,246

99,155

$99,108,155$

B.

D.

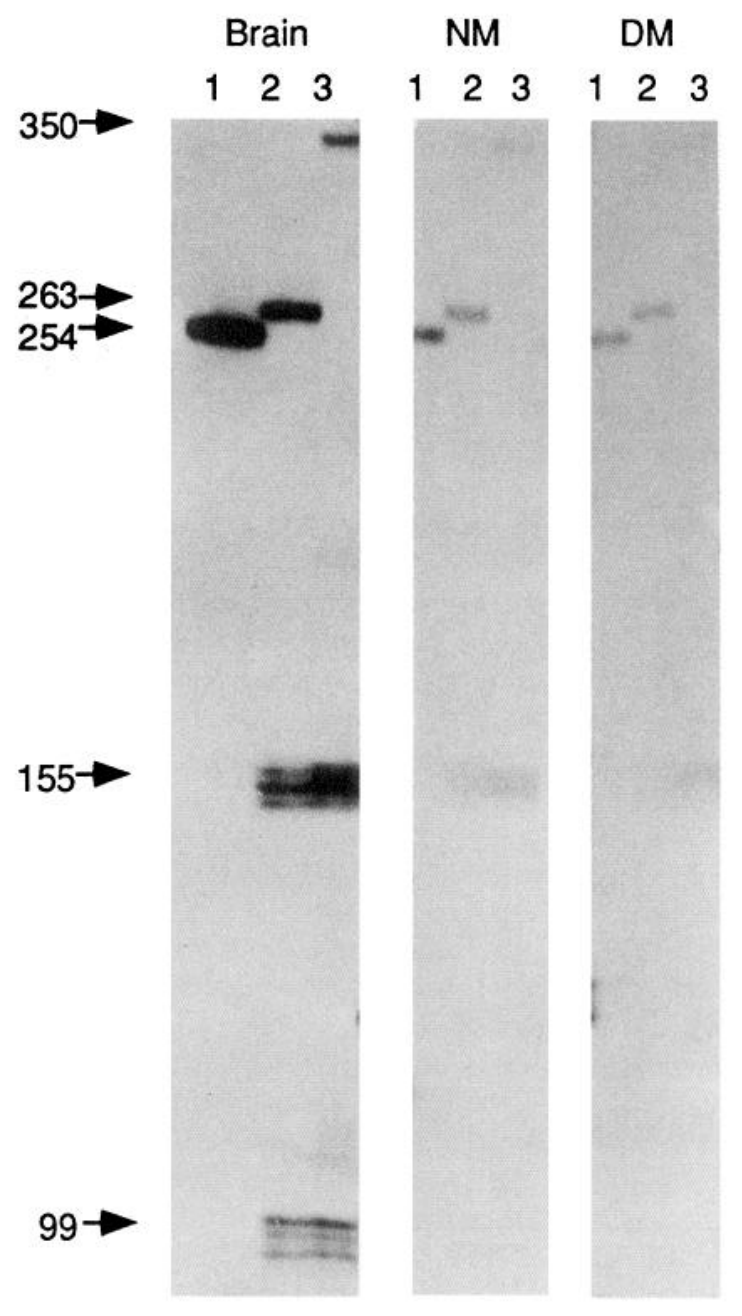

\section{B NM DM CM}

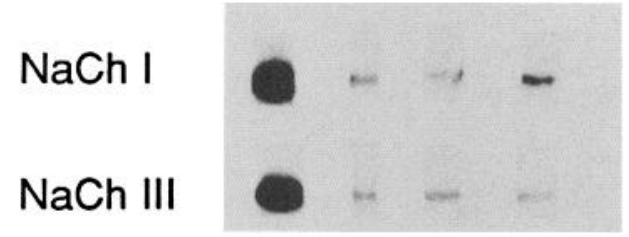

C.

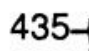

$402-$

$246 \rightarrow$

$156 \rightarrow$
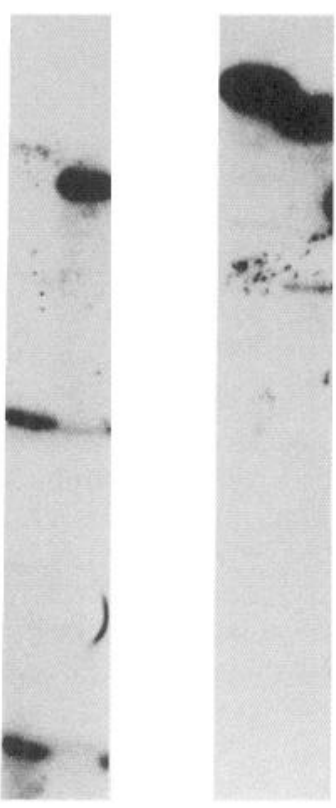

350

155

$99-$
Brain

Figure 5. RNase protection assay with probes to isoforms of $\mathrm{NaCh} \mathrm{I}$ and $\mathrm{NaCh}$ III. A, The broken line represents mRNA, and the solid line represents ${ }^{32} \mathrm{P}$-labeled riboprobe. The table indicates the sizes of the probe (in nucleotides) that are protected when binding to identical mRNA (Fully Protected) or to isoforms of each probe (Protected Fragments). Each of the five probes is 63 nucleotides longer than the fully protected size of the probes due to the polylinker. $B$, Protection of full length $\mathrm{NaCh}$ I and NaCh III probes to total RNA from brain $(B)$, normal skeletal muscle $(N M)$, denervated skeletal muscle $(D M)$, and cardiac muscle $(C M)$. Relative to the signal from brain RNA, the abundance in each tissue was measured for NaCh I $(N M, 8 \% ; D M, 8 \% ; C M, 13 \%)$ and NaCh III $(N M, 11 \% ; D M, 10 \% ; C M, 7 \%)$. C, Probes for NaCh I (lane I) and NaCh Ia (lane 2) hybridized to total RNA from rat brain. Intact ${ }^{32} \mathrm{P}$-labeled antisense riboprobe is shown for $\mathrm{NaCh} \mathrm{I} \mathrm{(lane} \mathrm{3)} \mathrm{and} \mathrm{NaCh}$ Ia (lane 4). D, Probes for $\mathrm{NaCh}$ III (lane 1), NaCh IIIa (lane 2), and NaCh IIIb (lane 3) hybridized to total RNA (50 $\mu \mathrm{g}$ ) from brain, normal skeletal muscle $(N M)$, and denervated skeletal muscle $(D M)$. Protected fragments at 99 and 155 nucleotides appear as triplets; these triplets also occur when NaCh IIIa antisense probe is hybridized to synthetic sense NaCh III RNA. Exposure time, $1 \mathrm{~d}(C), 2 \mathrm{~d}(B, D)$. 
Table 3. Isoforms of sodium channel genes found in brain, cardiac muscle, and skeletal muscle

\begin{tabular}{|c|c|c|c|}
\hline & Brain & Cardiac muscle & Skeletal muscle \\
\hline $\mathrm{NaCh} \mathrm{I}$ & I†, Iat* & $\mathrm{I}^{*}, \mathrm{Ia} \dagger^{*}$ & $\mathrm{I}^{+*}, \mathrm{Ia} \boldsymbol{\dagger}^{*}$ \\
\hline $\mathrm{NaCh}$ II & IIA $\dagger^{*}$ & Not detected $\dagger^{*}$ & Not detected $\dagger^{*}$ \\
\hline $\mathrm{NaCh}$ III & III $\dagger$, IIIa $\dagger$, IIIb $\dagger$ & III $\dagger^{*}$, IIIa $\dagger$, IIIb $\dagger$ & III $\rceil^{*}$, IIIa $\left.\right|^{*}$, IIIb $\dagger^{*}$ \\
\hline
\end{tabular}

The presence of these isoforms was detected by sequencing clones $\left(^{*}\right)$ and by RNase protection ( $\dagger$ ).

of mRNA for any isoform following skeletal muscle denervation ( $\mathrm{NaCh}$ Ia was not tested). RNase protection analysis provides an estimate of the relative steady state levels of mRNA. The differences we observe in isoform abundance could be due to differences in the rate of transcription or in the stability of the mRNA. Nevertheless, it is clear that $\mathrm{NaCh}$ I and NaCh III are transcribed in brain, cardiac muscle, and skeletal muscle. There are some $\mathrm{Na}$ channel genes whose transcription does appear to be restricted: $\mathrm{NaCh}$ II and $\mathrm{NaCh}$ IIA were not detected in muscle with either PCR or RNase protection (the $\mathrm{NaCh}$ II probe would protect both II and IIA), and $\mu 1$ was undetected in adult brain with RNase protection (data not shown). Thus, some, but not all, Na channel subtypes may be tissue specific (Table 3).

\section{Discussion}

Na channel cDNAs which code for the largest cytoplasmic domain were amplified by PCR. The primary focus of these studics was to determine the types of $\mathrm{Na}$ channel expressed in skeletal muscle. Sequencing of individual cDNA clones revealed a variety of $\mathrm{Na}$ channel isoforms in skeletal and cardiac muscle. The isoforms all occurred in one region of the cytoplasmic loop (asterisk in Fig. 1) and are best explained by alternative splicing events. All of the isoforms described here are either identical to or are variants of genes originally isolated from brain cDNA libraries; their role in muscle is unknown. The pattern of splicing suggests that the intron structure in this region of $\mathrm{NaCh} \mathrm{I,} \mathrm{NaCh}$ II, and $\mathrm{NaCh}$ III genes is similar.

\section{Alternative splicing}

Six different cDNA variants were cloned and sequenced from the reverse transcribed PCR reactions. When the brain genes ( $\mathrm{NaCh}$ I, NaCh II, and $\mathrm{NaCh}$ III) and the variant $\mathrm{cDNAs}$ were aligned by amino acid homology (Fig. 6), two features wcre evident. First, all the variability occurred in one region, specifically between the fourth and fifth consensus sites for cAMP phosphorylation in this cytoplasmic loop. Second, an inspection of the nucleotide sequence in this variable region strongly suggested that these variants are related by splicing of an intron that occurs at a homologous position in each of the three genes. When compared to $\mathrm{NaCh}$ I, both $\mathrm{NaCh}$ Ia and $\mathrm{NaCh}$ II have an identical 11 amino acids deleted. The first two nucleotides of the $\mathrm{NaCh}$ Ia deletion are GT, which are the consensus nucleotides for the $5^{\prime}$ donor site of an intron. Thus, the simplest explanation for this deletion is that there is an intron in $\mathrm{NaCh}$ I that occurs between amino acid 681 (N) and 682 (the $G$ of GTTTET in Fig. 6). NaCh la is formed when an extra 11 amino acids are deleted at the $5^{\prime}$ end. The isoforms are thus simply a consequence of the use of different $5^{\prime}$ splice sites. A similar argument can be made for $\mathrm{NaCh}$ II except that the 5 ' donor site is invariant and thus these 33 nucleotides are always included in the intron. The first 15 nucleotides of the 96 nucleotide insert of NaCh III are GTTAGTCAGGCCAGT. All of the isoforms of NaCh III, with one exception, can be explained by a similar variation in the $5^{\prime}$ splice site with the $5^{\prime}$ donors underlined in the sequence. The possible exception is NaCh IIIa where the two nucleotides following the nine nucleotide insert are GC rather than GT. Although the $5^{\prime}$ dinucleotide GT of an intron is almost invariant in higher eucaryotes, there are a few known exceptions and these have a GC (Green, 1986).

A protein's structure and function can be varied in a number of ways, including gene duplication with subsequent mutation, alternative splicing of RNA, and posttranslational modifications. Alternative splicing as a means of enhancing genetic diversity has been recently reviewed (Smith et al., 1989) and is utilized both in the nervous system where diversity of cellular function is paramount and in muscle for diversity of both regulatory and contractile proteins. Alternative splicing of ion channels is widespread and has been shown to be functionally important for both voltage-gated and ligand-gated channels.

There are reports of alternative splicing for voltage-gated $\mathrm{K}^{+}$, $\mathrm{Ca}^{2+}$, and $\mathrm{Na}^{+}$channels. Potassium channels in Drosphila are spliced at both the $5^{\prime}$ and $3^{\prime}$ ends of the cDNA (Kamb et al., 1988; Schwartz et al., 1988). The variants caused by splicing can have different kinetics, especially of inactivation (Timpe et al., 1988a,b; Stocker et al., 1990) and are differentially localized in the nervous system. A Drosophila Na channel, the para gene, is alternatively spliced (Loughney et al., 1989); two of the splice sites are in the first cytoplasmic loop but are not in positions homologous to those described here for rat $\mathrm{Na}$ channels. Thus, the Na channel is alternatively spliced in both insects and mammals. Calcium channels in the rat have recently been shown to be spliced (Tomlinson et al., 1990).

\section{Possible functional consequences of splicing}

Na channcls, likc many membranc proteins, are highly localized on the cell surface. In neurons, the node of Ranvier is densely packed with $\mathrm{Na}$ channels, and in muscle Na channels are concentrated at the neuromuscular junction (Beam et al., 1985; Caldwell et al., 1986; Roberts, 1987). Na channels can bind to the cytoskeletal-associated protein ankyrin (Srinivasan et al., 1988), and thin section immunocytochemistry suggests that both Na channels and ankyrin localize to the secondary folds of the neuromuscular junction (Flucher and Daniels, 1989). Variability in a cytoplasmic domain could be important for the differential localization of $\mathrm{Na}$ channels.

The first cytoplasmic loop (between domains I and II) is the largest and contains all five cAMP dependent protein kinase phosphorylation sites (Rossie et al., 1987). The region of variability due to alternative splicing occurs near the fourth protein kinase $\mathrm{A}$ site (indicated by the $\Delta$ in Fig. 6). Moreover, the variations between the different genes and isoforms creatc a mixturc of potential sites for phosphorylation by protein kinase $A$ and $C$ (Fig. 6). Changes in phosphorylation could be important for a wide range of $\mathrm{Na}$ channel properties. Activation of protein 


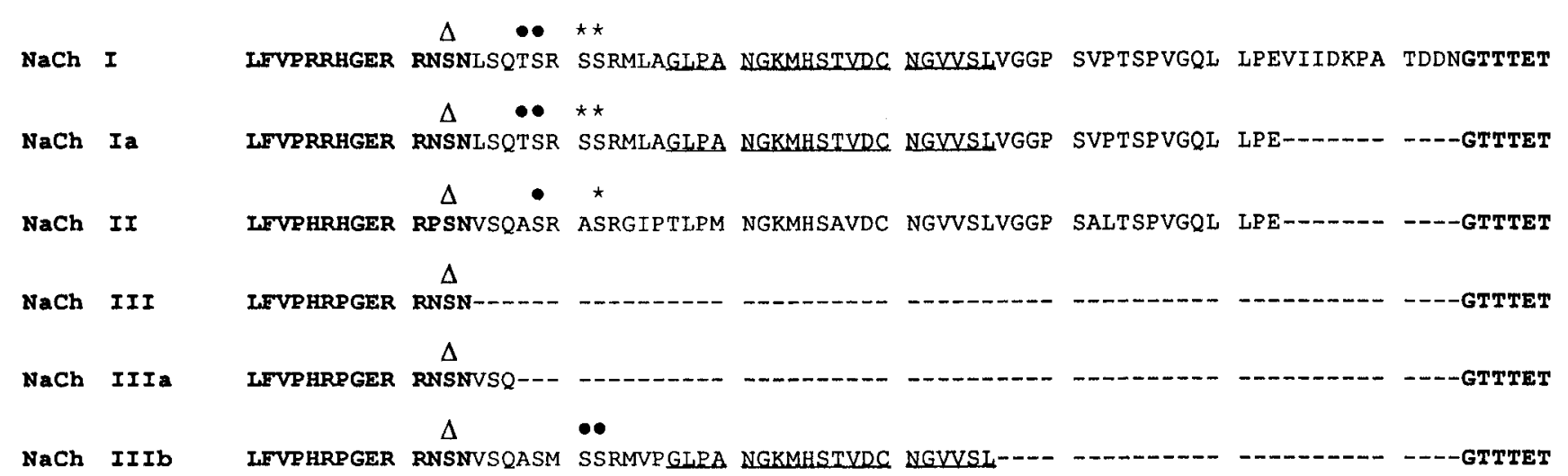

Figure 6. Alignment by amino acid homology of the variable region in the first cytoplasmic loop (asterisk in Fig. 1A). Amino acids surrounding the variable region are in boldface letters. Potential phosphorylation sites are indicated by symbols above the amino acids $(\Delta$, protein kinase $\mathrm{A} ; \bullet$, protein kinase $\mathrm{C}$; *, protein kinase $\mathrm{A}$ and $\mathrm{C}$ ). Standard single letter amino acid code is used.) The variable spliced intron would occur just before the GTTTET (in boldface letters). The underlined amino acids in NaCh IIIb are almost identical (58 out of 60) at the nucleotide level to the homologous region of $\mathrm{NaCh} \mathrm{I}$.

kinase $\mathrm{C}$ has been reported to cause a reduction of $\mathrm{Na}$ current (Sigel and Baur, 1988) and a change in voltage dependence (Dascal and Lotan, 1991). A similar change in phosphorylation might also explain a very slow recovery from inactivation of Na current (Almers et al., 1983; Simoncini and Stühmer, 1987). These phosphorylation sites could modulate channel interaction with cyloskeletal proteins such as ankyrin or alter interactions of the $\alpha$-subunits with $\beta$-subunits (Messner and Catterall, 1985; Roberts and Barchi, 1987).

In addition to the possible effects of these splicing variations upon cytoplasmic interactions, channel functions normally ascribed to extracellular domains could be altered. Two examples of variants created by alternative splicing for which there were transmembrane changes in function are a glutamate-activated channel (Sommer et al., 1990) and a voltage-gated potassium channel (Stocker et al., 1990).

Alternative splicing can be used to regulate gene expression. Bingham et al. (1988) estimate that $5 \%$ of gene regulation in Drosophila is at the level of RNA splicing. Transcription in this case would be constitutive, and splicing of an exon that includes a stop codon would produce a shortened, nonfunctional protein. We speculate that this might be a role for the transcript of $\mathrm{NaCh}$ III with the 13 nucleotide insert. This isoform is minor in adult brain and muscle but could be more abundant during development or in specific brain regions. Another role for the prematurely terminated isoform of $\mathrm{NaCh}$ III might be to create a truncated protein similar in size to a $\mathrm{K}^{+}$channel subunit. Stühmer et al. (1989) inserted a stop codon into $\mathrm{NaCh}$ II and created a $\mathrm{Na}$ channel protein terminated in the first cytoplasmic loop. When injected into oocytes, this short protein did not form functional channels; however, the cytoplasmic loop might be important for the assembly of subunits, and thus the point of termination might be critical. A test of this possibility would be to inject this isoform of $\mathrm{NaCh}$ III into Xenopus oocytes and determine if $\mathrm{Na}$ channels can be formed. The final, and perhaps most likely, explanation for the $\mathrm{NaCh}$ III transcript with the 13 nucleotide insert is that this is an incomplete or aberrant splice product.

\section{Brain transcripts in muscle}

Five different transcripts of Na channel cDNAs that were originally described as brain genes $(\mathrm{NaCh} \mathrm{I}$ and $\mathrm{NaCh}$ III) were found in cardiac and skeletal muscle (Table 3). Skeletal muscle in addition expresses two genes, $\mu 1$ and SkM2, that may be muscle specific. Thus, skeletal muscle can contain seven different $\mathrm{Na}$ channel transcripts. This is likely to be a lower limit since the cytoplasmic loop region described here is only about one-sixth of the coding region, and splicing in the rest of the cDNA could add further isoforms. In support of this, preliminary results indicate that splicing also occurs in the third major transmembrane domain. Alternative splicing in multiple regions [also observed in a Drosophila sodium channel (Loughney et al., 1989)] suggests that one should use caution when constructing a full-length cDNA from multiple overlapping cDNAs; the full-length cDNA might be a chimera of splice variants. Our conclusion that muscle contains many subtypes presupposes that all of these transcripts are translated into functional proteins, for which we have no evidence. Isotype-specific antibodies would be one means of answering this question.

The only genes cloned from muscle were similar to those of rat brain. Why did we not isolate $\mu 1$ or SkM2? When the project was begun, the only sequence information available was for genes from rat brain ( $\mathrm{NaCh}$ I, $\mathrm{NaCh}$ II, and $\mathrm{NaCh}$ III) and the eel electric organ. The primers were made nondegenerate and were highly conserved for these published genes. One of the primers, however, is not well conserved when compared to $\mu 1$ or SkM2. Our PCR conditions used relatively high temperatures for annealing, which reduced nonspecific amplification. Degenerate primers or lower annealing temperatures would have amplified $\mu 1$ or SkM2. We have amplified rat brain cDNAs from muscle with other nondegenerate primers from a different region of the Na channel (data not shown).

Could the brain clones isolated from muscle be contaminants from other clones in the laboratory? The PCR technique is extremely sensitive, and other laboratories have experienced amplification of contaminating DNA. The isoforms isolated from cardiac and skeletal muscles were first found in muscle and could not have resulted from contamination of plasmids with cDNA isolated from brain. Moreover, we have never amplified $\mathrm{NaCh}$ II or IIA from muscle RNA. Rat brain clones have been isolated from muscle cDNA libraries (Rogart et al., 1989). In adult heart, Rogart et al. (1989) estimated that $25-50 \%$ of the TTX binding is high affinity and three out of four clones isolated from the adult heart cDNA library were $\mathrm{NaCh}$ I. In 
addition, Suzuki et al. (1988) and Beckh (1990) detected NaCh I and $\mathrm{NaCh}$ III with hybridization of specific probes to skeletal muscle RNA (Northern analysis).

Another consideration arising from the sensitivity of the PCR technique is the possibility that the $\mathrm{Na}$ channel cDNAs we isolated came from nonmuscle cells that coexist with cardiac and skeletal muscle. Cardiac tissue contains parasympathetic neurons, and these might express $\mathrm{NaCh}$ I and/or $\mathrm{NaCh}$ III genes. An argument against the involvement of cardiac neurons is that Northern analysis of cultured cardiac myocytes showed a large signal with a NaCh I probe (Sills et al., 1989). Skeletal muscle contains Schwann cells (at the end plate) and satellite cells, both of which express Na channels (Chiu et al., 1984; Bader et al., 1988); these cells contribute a small fraction to the total muscle mRNA. We have amplified cDNAs from RNA isolated from rat sciatic nerve, which should provide RNA primarily from Schwann cells. Partial sequence analysis of the clones isolated indicated that they were $\mathrm{NaCh}$ II (or $\mathrm{NaCh}$ IIA) and $\mathrm{NaCh}$ III. This suggests that Schwann cell contamination was not a problem since no $\mathrm{NaCh}$ II was found in muscle. We cannot rule out the possibility that some $\mathrm{NaCh}$ I and $\mathrm{NaCh}$ III clones were amplified from satellite cell cDNA. In situ hybridization could resolve this question.

\section{Homologous 'gene structure}

Two homologies were evident from the data. The first is immediately obvious upon inspection of Figure 6: all of the splicing events coincide at the $3^{\prime}$ position (adjacent to amino acids GTTTET). The alignment of the different isoforms illustrated in Figure 6 suggests that the position of the intron-exon border is the same for all the genes, including $\mathrm{NaCh}$ II. Introns of related genes are often in homologous regions. The intron and exon structure of globin genes is a clearly documented example of this (Maniatis et al., 1980). Additional evidence for homologous introns in rat brain $\mathrm{Na}$ channels is the finding that an intron near the $5^{\prime}$ end of $\mathrm{NaCh} \mathrm{I}$ and $\mathrm{NaCh}$ II is at an homologous position in each gene (G. Mandel, personal communication). Thus, the genomic (intron and exon) organization is likely to be similar for many $\mathrm{Na}$ channel genes.

The second homology is more subtle and deals with nucleotide sequence identity between $\mathrm{NaCh}$ I and $\mathrm{NaCh}$ IIIb (the $96 \mathrm{nu}-$ cleotide insert). A 60 nucleotide region (coding for the amino acids underlined in Fig. 6) has 58 nucleotides that are identical to $\mathrm{NaCh}$ I. Thus, the splicing that created $\mathrm{NaCh}$ IIIb has the effect of inserting a portion of $\mathrm{NaCh} \mathrm{I}$ into $\mathrm{NaCh}$ III. Conservation of amino acids is often required to maintain function, but codon degeneracy allows amino acid conservation without complete nucleotide conservation. If we ignore bias of codon usage, 23 nucleotide positions could have hanged without changing amino acids; only two changes (9\%) were found. This is not the only region of $\mathrm{Na}$ channel genes in which there is a striking conservation at the nucleotide level. Pairwise comparisons of $\mathrm{NaCh}$ I, $\mathrm{NaCh}$ II, and $\mathrm{NaCh}$ III display many regions where there are no nucleotide mismatches ( 24 regions with $50-$ 100 identical nucleotides, 8 regions with $100-200$ identical nucleotides, and 2 regions with over 200 identical nucleotides). This patchwork homology can be explained by recent genc conversion events that are small. This process, called microconversions, has been demonstrated with mouse immunoglobulin genes cloned into yeast chromosomes (Wheeler et al., 1990). Another explanation for the conservation of nucleotides is that there is selective pressure to reduce the rate of mutation (perhaps due to sequences required for DNA or RNA binding factors or for sequences required for secondary structure). Usually, however, the conserved lengths of DNA due to binding factors are much shorter than those described here. Microconversion events may be a common feature of ion channel families, especially when there are repeating regions of homology. These nonallelic conversion events create and/or preserve a high degree of similarity between $\mathrm{Na}$ channel genes; this process should be considered when analyzing the evolution of the sodium channel gene family.

\section{References}

Almers W, Stanfield PR, Stühmer W (1983) Slow changes in currents through sodium channels in frog muscle membrane. J Physiol (Lond) 339:253-271.

Auld VJ, Goldin AL, Krafte DS, Marshall J, Dunn JM, Catterall WA, Lester HA, Davidson N, Dunn RJ (1988) A rat brain $\mathrm{Na}^{+}$channel $\alpha$ subunit with novel gating properties. Neuron 1:449-461.

Auld VJ, Goldin AL, Krafte DS, Catterall WA, Lester HA, Davidson N, Dunn RJ (1990) A neutral amino acid change in segment IIS4 dramatically alters the gating properties of the voltage-dependent sodium channel. Proc Natl Acad Sci USA 87:323-327.

Bader CR, Bertrand D, Cooper E, Mauro A (1988) Membrane currents of rat satellite cells attached to intact skeletal muscle fibers. Neuron 1:237-240.

Beam KG, Caldwell JH, Campbell DT (1985) Na channels in skeletal muscle concentrated near the neuromuscular junction. Nature 313: 588-590.

Beckh S (1990) Differential expression of sodium channel mRNAs in rat peripheral nervous system and innervated tissues. FEBS Lett 262 : 317-322.

Beckh S, Noda M, Lübbert H, Numa S (1989) Differential regulation of three sodium channel messenger RNAs in the rat central nervous system during development. EMBO J 8:3611-3616.

Bingham PM, Chou T-B, Mims I, Zachar Z (1988) On/off regulation of gene expression at the level of splicing. Trends Genet 4:134-138.

Caldwell JH, Campbell DT, Beam KG (1986) Na channel distribution in vertebrate skeletal muscle. J Gen Physiol 87:907-932.

Chiu SY, Schrager P, Ritchic JM (1984) Ncuronal-typc $\mathrm{Na}^{+}$and $\mathrm{K}^{+}$ channels in rabbit cultured Schwann cells. Nature 311:156-157.

Chomczynski P, Sacchi N (1987) Single-step method of RNA isolation by acid guanidinium thiocyanate-phenol-chloroform extraction. Anal Biochem 162:156-159.

Cooperman SS, Grubman SA, Barchi RL, Goodman RH, Mandel G (1987) Modulation of sodium-channel mRNA levels in rat skeletal muscle. Proc Natl Acad Sci USA 84:8721-8725.

Dascal N, Lotan I (1991) Activation of protein kinase C alters voltage dependence of a $\mathrm{Na}^{+}$channel. Neuron 6:165-175.

Flucher BE, Daniels MP (1989) Distribution of $\mathrm{Na}^{+}$channels and ankyrin in neuromuscular junctions is complementary to that of acetylcholine receptors and the $43 \mathrm{kd}$ protein. Neuron 3:163-175.

Gordon D, Merrick D, Auld V, Dunn R, Goldin AL, Davidson N, Callerall WA (1987) Tissue-specific expression of the RI and RII sodium channel subtypes. Proc Natl Acad Sci USA 84:8682-8686.

Green MR (1986) Pre-mRNA splicing. Annu Rev Genet 20:671-708.

Haimovich B, Schotland DL, Fieles WE, Barchi RL (1987) Localization of sodium channel subtypes in adult rat skeletal muscle using channel-specific monoclonal antibodies. J Neurosci 7:2957-2966.

Joho RH, Moorman JR, VanDongen AMJ, Kirsch GE, Silberberg H, Schuster G, Brown AM (1990) Toxin and kinetic profile of rat brain type III sodium channels expressed in Xenopus oocytes. Mol Brain Res 7:105-113.

Kallen RG, Sheng Z-H, Yang J, Chen L, Rogart RB, Barchi RL (1990) Primary structure and expression of a sodium channel characteristic of denervated and immature rat skeletal muscle. Neuron 4:233-242.

Kamb A, Tseng-Crank J, Tanouye MA (1988) Multiple products of the Drosophila Shaker gene may contribute to potassium channel diversity. Neuron 1:421-430.

Kayano T, Noda M, Flockerzi V, Takahashi H, Numa S (1988) Primary structure of rat brain sodium channel III deduced from the cDNA sequence. FEBS Lett 228:187-194.

Loughney K, Kreber R, Ganetzky B (1989) Molecular analysis of the para locus, a sodium channel gene in Drosophila. Cell 58:1 143-1154. 
Maniatis T, Fritsch EF, Lauer J, Lawn RM (1980) The molecular genetics of human hemoglobins. Annu Rev Genet 14:145-178.

Messing J (1983) New M13 vectors for cloning. Methods Enzymol 101:20-78.

Messner DJ, Catterall WA (1985) The sodium channel from rat brain: separation and characterization of subunits. J Biol Chem 260:1059710604.

Noda M, Shimizu S, Tanabe T, Takai T, Kayano T, Ikeda T, Takahashi H, Nakayama H, Kanaoka Y, Minamino N, Kangawa K, Matsuo H, Raftery MA, Hirose $T$, Inayama $S$, Hayashida $H$, Miyata $T$, Numa $S$ (1984) Primary structure of Electrophorus electricus sodium channel deduced from cDNA sequence. Nature 312:121-127.

Noda M, Ikeda T, Kayano T, Suzuki H, Takeshima H, Kurasaki M, Takahashi H, Numa S (1986a) Existence of distinct sodium channel messenger RNAs in rat brain. Nature 320:188-192.

Noda M, Ikeda T, Suzuki H, Takeshima H, Takahashi T, Kuno M Numa S (1986b) Expression of functional sodium channels from cloned cDNA. Nature 322:826-828.

Olivera BM, Rivier J, Clark C, Ramilo CA, Corpuz GP, $\Lambda$ bogadie FC Mena EE, Woodward SR, Hillyard DR, Cruz LJ (1990) Diversity of Conus neuropeptides. Science 249:257-263.

Redfern $P$, Theslerrs (1971) Action potential generation in denervated rat skeletal muscle. II. The action of tetrodotoxin. Acta Physiol Scand 82:70-78.

Roberts RH, Barchi RL (1987) The voltage-sensitive sodium channel from rabbit skeletal muscle. Chemical characterization of subunits. J Biol Chem 262:2298-2303.

Roberts WM (1987) Sodium channels near end-plates and nuclei of snake skeletal muscle. J Physiol (Lond) 388:213-232.

Rogart RB, Cribbs LL, Muglia LK, Kephart DD, Kaiser MW (1989) Molecular cloning of a putative tetrodotoxin-resistant rat heart $\mathrm{Na}^{+}$ channel isoform. Proc Natl Acad Sci USA 86:8170-8174.

Rossie S, Gordon D, Catterall WA (1987) Identification of an intracellular domain of the sodium channel having multiple cAMP-dependent phosphorylation sites. J Biol Chem 262:17530-17535.

Saiki RK, Gelfand DH, Stoffel S, Scharf SJ, Higuchi R, Horn GT, Mullis KB, Erlich HA (1988) Primer-directed enzymatic amplification of DNA with a thermostable DNA polymerase. Science 239:487-491.

Salkoff L, Butler A, Wei A, Scavarda N, Giffen K, Ifune C, Goodman R, Mandel G (1987) Genomic organization and deduced amino acid sequence of a putative sodium channel gene in Drosophila. Science 237:744-749.

Schwartz TL, Tempel BL, Papazian DM, Jan YN, Jan LY (1988) Multiple potassium-channel components are produced by alternative splicing at the Shaker locus in Drosophila. Nature 331:137-142.

Shull GE, Greeb J, Lingrel JB (1986) Molecular cloning of three distinct forms of the $\mathrm{Na}^{+}, \mathrm{K}^{+}$-ATPase $\alpha$-subunit from rat brain. Biochemistry 25:8125-8132.

Sigel E, Baur R (1988) Activation of protein kinase $C$ differentially modulates neuronal $\mathrm{Na}^{+}, \mathrm{Ca}^{++}$, and $\gamma$-aminobutyrate type A channels. Proc Natl Acad Sci USA 85:6192-6196.

Sills MN, Xu YC, Baracchini E, Goodman RH, Cooperman SS, Mandel G, Chien KR (1989) Expression of diverse $\mathrm{Na}^{+}$channel messenger RNAs in rat myocardium: evidence for a cardiac-specific $\mathrm{Na}^{+}$channel. J Clin Invest 84:331-336.
Simoncini L, Stühmer W (1987) Slow sodium channel inactivation in rat fast-twitch muscle. J Physiol (I ond) 383:327-337.

Smith CWJ, Patton JG, Nadal-Ginard B (1989) Alternative splicing in the control of gene expression. Annu Rev Genet 23:527-577.

Sommer B, Keinänen K, Verdoorn TA, Wisden W, Burnashev N, Herb A, Köhler M, Takagi T, Sakmann B, Seeburg PH (1990) Flip and flop: a cell-specific functional switch in glutamate-operated channels of the CNS. Science 249:1580-1585.

Southern EM (1975) Detection of specific sequences among DNA fragments separated by gel electrophoresis. J Mol Biol 98:503-517.

Srinivasan Y, Elmer L, Davis J, Bennett V, Angelides K (1988) Ankyrin and spectrin associate with voltage-dependent sodium channels in brain. Nature 333:177-180.

Stocker M, Wittka R, Wang X, Müller R, Ferrus A, Pongs O (1990) Alternative Shaker transcripts express either rapidly inactivating or noninactivating $\mathrm{K}^{+}$channels. Proc Natl Acad Sci USA 87:8903-8907.

Stühmer W, Conti F, Suzuki H, Wang X, Noda M, Yahagi N, Kubo $H$, Numa S (1989) Structural parts in activation and inactivation of the sodium channel. Nature 339:597-603.

Suzuki H, Beckh S, Kubo H, Yahagi N, Ishida H, Kayano T, Noda M, Numa S (1988) Functional expression of cloned cDNA encoding sodium channel III. FEBS Lett 228:195-200.

Timpe LC, Schwarz TL, Tempel BL, Papazian DM, Jan YN, Jan LY (1988a) Expression of functional potassium channels from Shaker cDNA in Xenopus oocytes. Nature 331:143-145.

Timpe LC, Jan YN, Jan LY (1988b) Four cDNA clones from the Shaker locus of Drosophila induce kinetically distinct A-type potassium currents in Xenopus oocytes. Neuron 1:659-667.

Tomlinson WJ, Gilbert MM, Snutch TP (1990) Distinct rat brain class- $C$ calcium channels are generated by alternative splicing. Soc Neurosci Abstr 16:957.

Trimmer JS, Cooperman SS, Tomiko SA, Zhou J, Crean SM, Boyle MB, Kallen RG, Sheng Z, Barchi RL, Sigworth FJ, Goodman RH, Agnew WS, Mandel G (1989) Primary structure and functional expression of a mammalian skeletal muscle sodium channel. Neuron 3:33-49.

Trimmer JS, Cooperman SS, Agnew WS, Mandel G (1990) Regulation of muscle sodium channel transcripts during development and in response to denervation. Dev Biol 142:360-367.

Weiss RE, Horn R (1986) Functional differences between two classes of sodium channels in developing rat skeletal muscle. Science 233: $361-364$.

Westenbroek RE, Merrick DK, Catterall WA (1989) Differential subcellular localization of the $R_{1}$ and $R_{I I} \mathrm{Na}^{+}$channel subtypes in central neurons. Neuron 3:695-704.

Wheeler CJ, Maloney D, Fogel S, Goodenow RS (1990) Microconversion between murine $\mathrm{H}-2$ genes integrated into ycast. Nature 347: 192-194.

Wollner DA, Catterall WA (1985) Antigenic differences among the voltage-sensitive sodium channels in the peripheral and central nervous systems and skeletal muscle. Brain Res 331:145-149.

Wollner DA, Catterall WA (1986) Localization of sodium channels in axon hillocks and initial segments of retinal ganglion cells. Proc Natl Acad Sci USA 83:8424-8428. 